\title{
The Improvement of Mathematical Connection Ability and Habits of Students' Mind with Missouri Mathematics Project and Discovery Learning
}

\author{
Aditya Prihandhika, S Fatimah \\ Postgraduate School, Universitas Pendidikan \\ Indonesia, Bandung - Indonesia. \\ adityaprihandhika@student.upi.edu, \\ sitifatimah@upi.edu
}

\author{
D Dasari \\ Postgraduate School, Universitas Pendidikan \\ Indonesia, Bandung - Indonesia. \\ dasari@upi.edu
}

\begin{abstract}
This study aims to analyse the improvement of mathematical connection ability and the habits of students' mind who are taught by using the Missouri Mathematics Project (MMP) model and Discovery Learning (DL) model. This type of research belongs to quasi experiment using quantitative and qualitative data analysis. Quantitative data were obtained from the pretest and posttest of mathematical connection ability in derivative material and questionnaire scale of the habits of mind analysed by SPSS 20 for Windows software. While the qualitative data were obtained from the results of observations and interviews. The sample were 70 students who divided into two experimental classes. Based on the t-test results from the average $\mathrm{N}$-gain score indicates that there is a difference in the increase of mathematical connection ability of students with the improvement of mathematical connection in MMP class that is better than DL class. Meanwhile, based on mann whitney-u test result from mean of posttest of questionnaire indicate that there is no difference of achievement of students' habits of mind in both experiment class. That is, the achievement of habits of mind in the MMP class and the DL class is relatively the same.
\end{abstract}

Keywords - Mathematical Connection, Habits of Mind, Missouri Mathematics Project, Discovery Learning

\section{INTRODUCTION}

The 2015 Trends in International Mathematics and Sciene Study (TIMSS) findings show that the average achievement of Indonesian students' mathematical ability was ranked 51st of 55 countries, at a low level below the international median and lagging far behind neighboring countries such as Malaysia, Singapore and Thailand [1]. This fact is reinforced by the results of the 2015 PISA (Program for International Student Assessment) survey shows that the competence of Indonesian students mathematics was at the average score of 386. The achievement is still below the OECD standard (Organizational for Economic Cooperation and Development) standard with the average score of 490 [2]. Whereas according to Rahmawati, the percentage of students who have been taught the topics tested in TIMSS and PISA ranges in the number $74 \%$ [3]. The percentage is higher than some top performers countries such as China 55\%, Hongkong 52\%, and
Singapore 40\%. It shows that the learning process implemented by the teacher (applied curriculum) is not in tandem with the achievement of learning attained by students (attained curriculum). Based on the findings of TIMSS and PISA as described, Nizam (2016) stated that one of the factors causing low attainment of mathematical ability was the affective factor or internal factor of students [4].

More specifically these factors are self-confidence in mathematics which shows only $23 \%$ of students are confident in their mathematical skills. It shows that the affective ability of the students also have an influence in the success of learning. Louis \& Sutton stated that the effectiveness of students in the learning process was not only determined fully by the cognitive ability possessed, but also determined by how well the students were in utilizing affective skills [5]. Affective abilities here mean the attitudes, interests, and emotions that the students has for assessing something in the process of obtaining information during learning. One of the most important affective abilities that must be have by students is habits of mind.

But the results of research by Setiawati in one of the senior high school indicate that the students have habits of mind with less category [6]. Students seem to give up easily, not listening with understanding and empathy, still timid in asking and raising problems. This is because students are less able to apply the past knowledge in learning mathematics. The application of past knowledge in solving mathematical problems is closely related to the ability of mathematical connections. Astuti said that the ability of mathematical connections helps students to analyse mathematical problems, relate mathematical concepts, understand why concepts were used, draw conclusions, then communicate ideas correctly [7]. Therefore, a learning model is needed to improve the mathematical connections of the students.

According to Hanson, an effective learning model was a model that emphasises the process of building understanding, self-centered knowledge, experience, skills, attitudes and 
beliefs, working in small groups, training in analysing a problem by constructing and linking mathematical ideas [8]. Learning models that can be used to help students improve their strength as learners are the Missouri Mathematical Project (MMP) model and the Discovery Learning (DL) model. Purwanti stated that the application of MMP model in learning can provide opportunities for students to be able to cooperate in groups in controlled exercises that teachers provide by utilising the knowledge and experience that they already have [9]. Meanwhile, Bahm stated that the application of DL model in learning was one of the variations of the way of teaching that was able to make students can be active in learning process [10]. Based on the above explanation, the researcher considers it necessary to conduct a study to explore factors that influence the mathematical connection ability and habits of mind students and to examine whether there are differences in the effectiveness of the Missouri Mathematics Project (MMP) model and the Discovery Learning (DL) model to improve the ability of mathematical connections and habits of mind students.

\section{REVIEW OF LITERATURE}

\section{A. The Ability of Mathematical Connection}

Connection in mathematics is a relationship of ideas or ideas that used to formulate and test mathematical topics deductively. Mathematical concepts and procedures were developed to solve mathematical problems as well as science other than mathematics. NCTM states that indicators for mathematical connection ability include : 1) recognising and exploiting relationships between ideas in mathematics ; 2) understand how ideas in mathematics interconnect and underlie each other to produce a coherent whole ; 3) recognize and apply mathematics in contexts outside mathematics [11].

\section{B. Habits of Mind}

Habits of mind is an affective ability that encourages students to behave intellectually or intelligently when faced with problems, both in learning and in everyday life. Costa and Kallick identified sixteen such characteristics as follows : 1) persisting or unyielding ; 2) arranging conscience ; 3) listening to the opinions of others with a sense of empathy ; 4) smooth thinking ; 5) metacognitive thnking ; 6) trying to work meticulously and precisely ; 7) ask and issue problems effectively ; 8) utilising old experiences to form new knowledge ; 9) think and communicate clearly and precisely ; 10) leverage the senses in collecting and processing data ; 11) creating, imagine, and innovate ; 12) eager in responding ; 13) dare to be responsible and at risk ; 14) humorous ; 15) thinking of each other ; 16) and continuing learning [12].

\section{Missouri Mathematics Project Model}

According to Good and Grouws, MMP was a model designed to help teachers actively use exercises that aim to enable students to be creative in integrating different knowledge and skills, giving them the opportunity to formulate questions and try to answer them, giving problems as an alternative way of demonstrating learning and enhancing the competence of students, providing opportunities to interact positively and in collaboration with their classmates, and providing a forum to share their knowledge [13]. The learning steps in the MMP model include review (students remember the material that has been learned), development (students explore the concept deeply), cooperative working (students work together in solving problems), seat work (students practice in a way independent), and assignment (students get project to increase knowledge).

\section{Discovery Learning Model}

According to Bruner the DL model encourages students to ask questions and draw conclusions from general principles [14]. Hosnan states that the main characteristic of learning was finding, that is exploring and solving problems to create, combining new knowledge and existing knowledge [15]. The learning steps in the DL model include stimulation (students are given interesting issues), problem statement (students are invited to solve problems given), data collecting and data processing (students collect and process information to solve problems), verification (students confirm the truth of the solution) and generalization (students deduce the knowledge that has been obtained).

\section{METHOD}

This research was used quasi experiment design with quantitative data analysis and qualitative data analysis. Quantitative data were obtained from pretest and posttest data of instrument of mathematical connection ability in derivative material and questionnaire of habits of mind scale that has fulfilled the validity and reliability requirement. While the qualitative data were obtained from the results of observations and interviews conducted on teachers and students. The subjectss were 70 students who divided into two experimental classes based on purposive sampling technique by Sugiyono [16] with MMP model in experimental class 1 and DL model in experimental class 2

Quantitative data analysis uses the help of SPSS 20 for Windows program to see differences in mathematical connection capability based on $\mathrm{N}$-gain mathematical connection ability and difference of habits of mind based on posttest result of habits of mind scale. The statistical tests performed include prerequisite test (normality test with shapiro-wilk and homogeneity test of statistical levene), and test the difference of two averages with parametric statistics ( $t$ test) or nonparametric statistics (Mann Whitney-U test) determined based on the results of the prerequisite test with an $\boldsymbol{\alpha}$ significance level of 0.05 .

While the analysis of qualitative data on the results of interviews done by stages according to Miles, Mathew and Huberman that was reduced by selection and simplification of the data obtained [17]. Then present the data and give a conclusion. Qualitative data aims to strengthen or weaken the 
results from statistical tests on quantitative data analysis based on actual circumstances.

\section{RESUlts AND DisCUSSION}

\section{A. Results}

In this chapter, a statistical analysis describe the acquisition of pretest and posttest score that was given before and after the implementation of MMP model in experimental class 1 and DL model in experimental class 2 . The mean of $\mathrm{N}$ gain score shows the quality improvement of mathematical connection ability based on category by Melter [18]. In addition, also presented the statistical analysis that describe the average acquisition percentage of habits of mind scale of students based on posttest questionnaire after treatment. Table 1 shows the average score of pretest, posttest and N-gain score of mathematical connection ability students.

TABLE I. DESCRIPTION OF THE MEAN SCORES OF PRETEST, POSTTEST AND N-GAIN MATHEMATICAL CONNECTION ABILITY

\begin{tabular}{|c|c|c|c|c|}
\hline Class & \multirow{2}{*}{ Data } & \multicolumn{3}{|c|}{ Results } \\
\cline { 3 - 4 } & & $\mathrm{s}$ & $\overline{\boldsymbol{x}}$ & $\mathrm{N}$ \\
\hline \multirow{3}{*}{ MMP } & Pretest & 2,77 & 4,91 & \\
& Posttest & 4,47 & 17,29 & \multirow{3}{*}{35} \\
\cline { 2 - 4 } & N-Gain & 0,18 & 0,49 & \\
\hline \multirow{2}{*}{ DL } & Pretest & 2,86 & 4,94 & \multirow{3}{*}{35} \\
\cline { 2 - 4 } & Posttest & 6,33 & 13,63 & \\
\cline { 2 - 4 } & N-Gain & 0,24 & 0,35 & \\
\hline
\end{tabular}

Referring to table 1, the acquisition of pretest score on the MMP grade is 4.91 and 4.94 for the DL class. It can be seen that the acquisition of the pretest mean of the two classes is not very different. Furthermore, the acquisition of posttest score in MMP class is 17, 29 and in DL class is 13,63. It appears that the average gain of posttest in the MMP class is better than the DL class. While the average gain of $\mathrm{N}$-gain score in the MMP class is 0.49 and the DL class is 0.35 . It can be seen that the acquisition of average $\mathrm{N}$-gain scores in the MMP class is better than the DL class although the quality of the mathematical connection capability of the two classes belongs to the medium category with reference to the $\mathrm{N}$-gain classifications. Figure 1 and Figure 2 show the comparison of the average score of pretest, posttest and $\mathrm{N}$-gain.

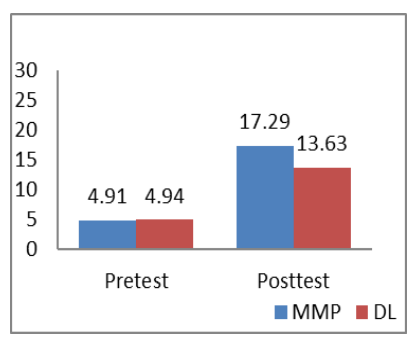

Figure.1.Means of pretest and posttest score mathematical connection ability.

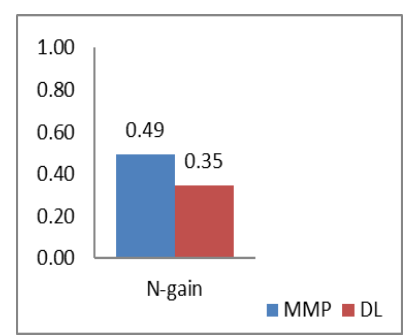

Figure.2. Means of N-gain score mathematical connections improved.
From the graph view in Figure 1 and Figure 2, the graph of average pretest scores in the two classes is not too different. While the graph of the average posttest score and the average $\mathrm{N}$-gain score of MMP class is higher than the DL class. While the Table 2 presents the statistical description of the percentage of habits of mind of the students in the two classes.

TABLE II. DESCRIPTION PERCENTAGE SCALE HABITS OF MIND STUDENTS

\begin{tabular}{ccccc}
\hline \multirow{2}{*}{ Class } & \multicolumn{5}{c}{ Habits of Mind Scale } \\
\cline { 2 - 5 } & $\mathrm{N}$ & $\mathrm{X}_{\min }$ & $\mathrm{X}_{\max }$ & $\overline{\mathbf{x}}$ \\
\hline MMP & 35 & 42,98 & 78,95 & 56,00 \\
\hline DL & 35 & 46,49 & 79,82 & 54,70 \\
\hline Maksimum Score (\%) & \multicolumn{5}{c}{100} \\
\hline
\end{tabular}

Referring to table 2, it is known that the mean percentage of habits of mind of students in the MMP class is $56.00 \%$. While in the class DL is equal to $54.70 \%$. If seen from the acquisition of the average scale of habits of mind from both experimental classes, the average acquisition of habits of mind scale of students in the MMP class is better than DL class learners with a difference that is equal to $1.30 \%$. Figure 3 below shows the comparison of the percentage of habits of mind of learners in the two classes.

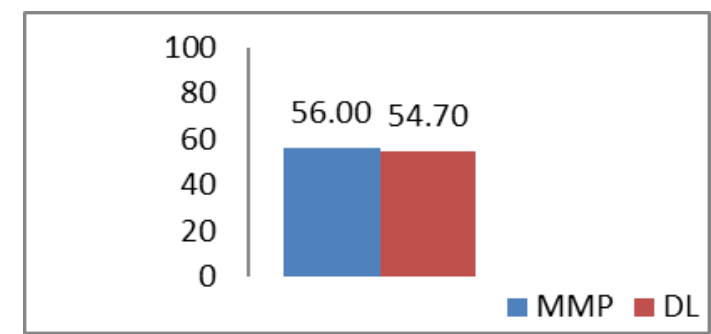

Figure 3: Percentage of habits of mind scale.

Seen in Figure 3, the graph of achievement of students' habits of mind in MMP class and DL class is relatively the same. But statistical tests need to be performed to show that the ability of habits of mind students in the two classes did not different significantly.

\section{Analysis of Mathematical Connection Capability Improvement}

Based on the prerequisite test results, it can be concluded that the average score of mathematical connection ability in both classes meets the normality and homogeneity requirements. Furthermore, parametric statistic test will be performed that is t-test to know the difference of improvement of mathematical connection ability of students in both experiment class. The test was done with significance level $\alpha$ $=0,05$. If the value of sig. (2-tailed) $>\alpha$ then $\boldsymbol{H}_{\mathbf{0}}$ is accepted, the opposite condition if the value of sig. (2-tailed) $\leq \alpha$ then $\boldsymbol{H}_{0}$ is rejected. The statistical hypothesis for $\boldsymbol{H}_{\mathbf{0}}$ is that there is no difference in the increase in mathematical connection ability between students who obtained the MMP model with students who obtained the DL model. Table 3 shows the t-test results. 
TABLE III. RESULT OF T-TEST MEANS SCORE N-GAIN

\begin{tabular}{|c|c|c|c|c|}
\hline$t$ & $\mathrm{df}$ & $\begin{array}{c}\text { Sig. (2 } \\
\text {-tailed })\end{array}$ & Decision & Information \\
\hline 2,7 & 68 & 0,007 & $\mathrm{H}_{\mathrm{o}}$ rejected & There is difference \\
78 & & & \\
\hline
\end{tabular}

Referring to the result of a statistic, the value of sig. (2tailed) is $0,007<\boldsymbol{\alpha}$, then $\boldsymbol{H}_{0}$ is rejected. Thus, it can be concluded that there is a difference in the increase of mathematical connection ability based on $\mathrm{N}$-gain score between students taught by MMP model and DL model. Further to know which learning model is better in improving the mathematical connection ability of students, conducted hypothesis testing based on the results of statistical tests presented in table 3 .

The test criterion was that if the value of $1 / 2 \operatorname{sig}(2$-tailed) > $\boldsymbol{\alpha}$ then $H_{0}$ is accepted, the opposite condition if the value of $1 / 2$ $\operatorname{sig}\left(2\right.$-tailed) $<\boldsymbol{\alpha}$ then $H_{0}$ is rejected. The statistical hypothesis for $H_{0}$ is the enhancement of mathematical connection capability of students who obtain MMP class no better than DL class. Based on the results of the analysis, obtained the value of $1 / 2 \mathrm{sig}$. (2-tailed) $<\boldsymbol{\alpha}$ then $H_{0}$ rejected. Thus enhancement of mathematical connection ability of students who get MMP class was better than DL class. So it can be concluded that the MMP model was more effective in improving the ability of mathematical connections of students.

\section{Analysis of the Achievement of Habits of Mind}

To analyse the achievement of habits of mind of students, the statistical test used was Mann Whitney-U test. This because the scale data was derived from two independent classes, ordinal, and assumed not to be normally distributed by Lestari and Yudhanegara [19]. The test criteria used were if the value of sig. (2-tailed) $<\boldsymbol{\alpha}(\boldsymbol{\alpha}=0,05)$, then $H_{0}$ is rejected. For other conditions, if the sig value (2-tailed) $\geq \boldsymbol{\alpha} \quad(\boldsymbol{\alpha}=0,05)$, then $H_{0}$ is accepted. The statistical hypothesis for $H_{0}$ is that there is no difference in the attainment of habits of mind between students who obtained the MMP model with the students who obtained the DL model. Results of mann whitney-u statistical test are presented in table 4 .

TABLE IV. RESULT OF MANN WHITNEY-U TEST THE HABITS OF MIND SCALE

\begin{tabular}{|c|c|c|c|c|}
\hline $\begin{array}{c}\text { Mann } \\
\text { Whitney-U }\end{array}$ & $\mathrm{N}$ & Sig. $(2-$ tailed $)$ & Decision & Information \\
\hline 526 & 70 & 0,309 & $\mathrm{H}_{\mathrm{o}}$ accepted & $\begin{array}{c}\text { There is no } \\
\text { difference }\end{array}$ \\
\hline
\end{tabular}

Referring to the result of statistical test, value of sig (2tailed) is obtained that equal to $0.309>\alpha$, then $\boldsymbol{H}_{\mathbf{0}}$ is accepted. Thus, it can be concluded that there was no significant difference in the attainment of the habits of mind between students who obtained the MMP model with the students who obtained the DL model.

\section{B. Discussion}

Table 3. Result of t-test means score $\mathrm{N}$-gain

From the results of quantitative data analysis, it can be concluded that the improvement of mathematical connection ability of students in MMP class is better than DL class. This means that the learning steps on the MMP model are quite effective in improving the mathematical connection ability of students. While the attainment of habits of mind in both classes there is no significant difference. It shows that both learning models have the same effect in improving the habits of mind of students. When viewed from the result of pretest and posttest answers, there are different ways to answer during pretest and also posttest. An example of a pretest answer to students is shown in figure 4 and figure 5 as follows

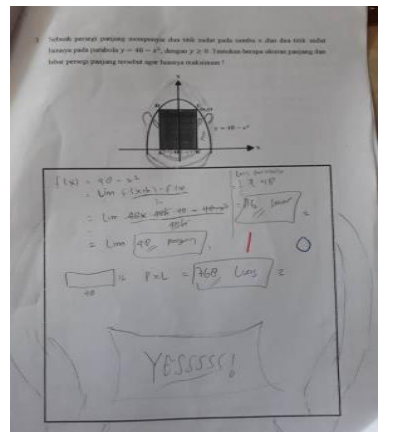

Figure 4: Example a pretest student MMP answer

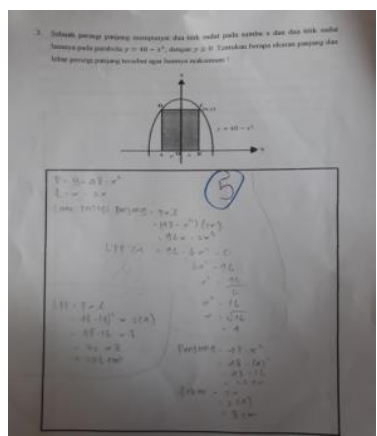

Figure 5: Example a pretest student DL answer
Referring to Figure 4, in the pretest response result before treatment, one of the student in MMP class showed that he did not fill the answer at all, referring to the connection indicator, there is no mathematical idea written in solving the problem. Referring to the habits of mind, the student seemed instantly surrendered and did not try to solve the problem. While based on figure 5 , on the pretest response result before treatment, one of the students in DL class showed that he was used the concept of limit to solve the problem. But in the end the he seem frustrated and do not continue his effort. Furthermore the students' posttest answers in both classes after treatment, are shown in figures 6 and 7 as follows.

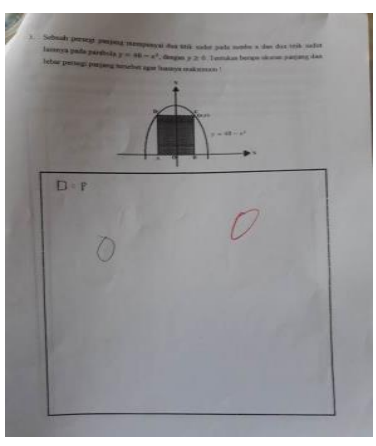

Figure 6: Example a posttest student MMP answer

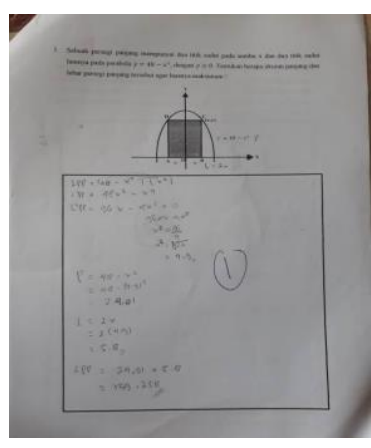

Figure7: Example of a pretest student DL answer
Referring to Figure 6, on posttest response results after treatment, one of the students in the MMP class was able to solve the problem completely and correctly. He was able to apply ideas of derivative material to solve a given problem. And in the pretest, there were no ideas that he wrote. While in 
figure 7, on the posttest response after treatment, one of the students in the DL class was seen writing down the ideas on the derived material, but he were not careful in completing the equation. Overall, the mean $\mathrm{N}$-gain in both classes increased after the treatment was given. Based on the results of observation and interviews, the following findings are obtained : 1) the interest and enthusiasm of students in learning must be considered ; 2) students are less accustomed to solving mathematical application problems in life so that at the time of their pretest they seem unprepared ; 3) the way teachers in teaching affect the formation of habits of mind students ; 4) the students feel that the treatment provided by both MMP model and DL model is in accordance with what they expect in learning.

\section{CONCLUSION}

From the results and the discussion obtained some conclusions include: 1) the students should be familiarized to get the applicable and non-routine mathematical problems to train its ability; 2) MMP model and DL model have contributed in improving mathematical connection ability in terms of the mean of pretest and posttest scores ; 3) The MMP model is more effective in enhancing the mathematical connections of students ; 4) The steps in the MMP model that very useful in improving the mathematical connection ability of students are review and assignment step ; 5) To improve the habits of mind students takes longer research time ; 6) Overall, the habits of mind students in both classes is better than the initial conditions before the study. This is because they feel happy in mathematics learning process and confident for their knowledge after obtaining the MMP model learning and DL model learning.

\section{REFERENCES}

[1] L. R. Jones, G. Wheeler, and V. A. Centurino, V. A, TIMSS 2015 Science Framework. TIMSS, pp. 29-59, 2015.

[2] OECD, PISA 2015: Results In Focus, 2016.
[3] S. Rahmawati, Pemahaman dan Koneksi Matematis serta Habits of Mind siswa SMA melalui Pembelajaran M-APOS, Thesis SPS UPI : Tidak diterbitkan, 2016.

[4] Nizam, Ringkasan Hasil-hasil Asesmen Belajar dari Hasil UN, PISA, TIMSS, INAP, 2016.

[5] M. R. Louis, and R. I. Sutton, "Switching cognitive gears: From habits of mind to active thinking", Human relations, vol. 44, no. 1, pp. 55-76, 1991.

[6] E. Setiawati, Mengembangkan Kemampuan Berpikir Logis, Kreatif, dan Habits Of Mind Matematis melalui Pembelajaran Berbasis Masalah: Eksperimen terhadap Siswa Madrasah Aliyah, Doctoral dissertation: Universitas Pendidikan Indonesia, 2014

[7] P. Astuti, "Pengembangan LKS Berbasis Pendekatan Pemodelan Matematika untuk Melatih Kemampuan Koneksi Matematis Siswa SMP Kelas VIII", Jurnal Pendidikan Matematika, vol. 11, no. 2, 2015.

[8] D. Hanson, Instructor's guide to process-oriented guided-inquiry learning, Lacey Avenue : Pacifik Crest, 2006.

[9] S. P. S. Purwanti, Meningkatkan Kemampuan Komunikasi dan Berpikir Kritis Matematis Siswa Sekolah Dasar dengan Model Missouri Mathematics Project (MMP, Jurnal Terampil, vol. 4, no. 2, p. 15, 2015.

[10] A. G. Bahm, "The Effects of Discovery Learning on Students' Succes and Inquiry Learning Skills", Egilim Arastirmalari-Eurasian Journal of Educational Research, vol. 35, pp. 1-20, 2009.

[11] NCTM, Principle and Standards for School Mathematics, Reston, VA: NCTM, 2000

[12] A. L. Costa and B. Kallick, Learning and leading with habits of mind: 16 essential characteristics for success, ASCD, 2008.

[13] T. L. Good and D. A. Grouws, "The Missouri Mathematics Effectiveness Project: An experimental study in fourth-grade classrooms", Journal of educational psychology, vol. 71, no. 3, 1979.

[14] J. S. Bruner, The act of discovery, Harvard educational review, 1961.

[15] M. Hosnan, Pendekatan Saintifik dan Kontekstual dalam Pembelajaran Abad 21, Bogor: Ghalia Indonesia, 2004.

[16] Sugiyono, Metode Penelitian Pendidikan Pendekatan Kuantitatif, Kualitatif, dan R\&D, Bandung: Alfabeta, 2004.

[17] Miles, B. Mathew and A. M. Huberman, Analisis Data Kualitatif, Jakarta : Universitas Indonesia Press, 1992.

[18] D. E. Meltzer, "The Relationship between Mathematics Preparation and Conceptual Learning Gains in Physics: a Possible "Hidden Variable" in Diagnostic Pretest Score" American Journal of Physics, vol. 70, no. 12, pp. 1259-1268, 2009.

[19] K. E. Lestari and M. R. Yudhanegara, Penelitian pendidikan matematika, Bandung: Refika Aditama, 2009. 